Research article

\title{
Diabetic Patients' Family's Health Beliefs Toward Diabetes Prevention and The Contributing Factors
}

\author{
Titis Kurniawan¹, Irfani Nurfuadah², Dian Adiningsih ${ }^{3}$ \\ 1,2,3 Fakultas Keperawatan Universitas Padjadjaran, Bandung Indonesia
}

\section{Article Info}

\section{Article History:}

Accepted Oct 28th, 2020

\section{Keywords:}

Diabetes Mellitus; Family; Health Belief Model (HBM); Prevention Behavior

\section{PENDAHULUAN}

International Diabetes Federation [IDF], (2019) dan World Health Organization [WHO], (2018) mencatat bahwa diabetes mellitus (DM) merupakan masalah kesehatan serius di dunia dengan jumlah penderita yang terus bertambah secara masif. Tercatat bahwa pada tahun 2019 secara global ada 463 juta penderita Dm dan diprediksi akan meningkat menjadi

\begin{abstract}
Health beliefs among family members of diabetic patients are important factor of the diabetic preventing behaviours. This study aimed to describe family's beliefs toward diabetes mellitus prevention based on the Health Belief Model and its' contributing factors. This corelational study involved 72 peoples that purposively sampled from 34 diabetic patients' family members who live in Jatinangor Public Health Center Working area. A questionnaire developed by the research team consisted of 37 items and 6 domains: perceived susceptibility, severity, benefits, barriers, cues to action, and self efficacy was used to collect the data. The collected data were analyzed descriptively and inferentially. The results showed that most of respondents $(77.78 \%)$ positively believed on diabetes mellitus (DM) susceptibility, severity (59.72\%), benefits of DM prevention $(84.77 \%)$, and cues to action (76.4\%). It was also found that most of respondents negatively believed on the prevention barriers (84\%) and self-efficacy (77.78\%). Female and actively involved in patient care seemed to be the contributing factors of the respondents' beliefs related to DM prevention. To conclude, the DM patients' family members believed that they are vulnerable to have DM and DM preventions are beneficial. Female and being actively involved in patient care potentially increase the family members' beliefs toward DM prevention. So, it is important for the healthcare professionals to maximize the family members' involvement in DM patient care program.
\end{abstract}

51\% menjadi 700 juta jiwa pada tahun 2045 (IDF, 2019). Lebih lanjut, dilaporkan bahwa prevalensi DM di Indonesia menduduki peringkat ketujuh terbanyak di dunia dengan jumlah penderita sebanyak 10,7 juta jiwa pada tahun 2019 dan diprediksi meningkat menjadi 16,6 juta jiwa pada tahun 2045 (IDF, 2019). Proporsi kedua terbesar penduduk Indonesia yang terdiagnosis DM berada di Provinsi Jawa Barat (Pusat Data dan informasi

\footnotetext{
Corresponding author:

Titis Kurniawan

t.kurniawan@unpad.ac.id

Media Keperawatan Indonesia, Vol 3 No 3, October 2020

e-ISSN: 2615-1669

ISSN: 2722-2802

DOI: https://doi.org/10.26714/mki.3.3.2020.175-185
} 
Kementerian Keseahatan RI, 2014).

Selain jumlah yang terus bertambah, penyakit diabetes juga merupakan masalah kesehatan global yang serius akibat komplikasi dan dampak negatif lanjut yang ditimbulkannya (IDF, 2019). Beberapa studi juga menemukan bahwa banyak pasien diabetes yang juga menderita stroke (31.8\% - 59.3\%) (Law et al., 2015; Rao \& Reddy, 2016), penyakit jantung (25\% 40\%) (Einarson et al., 2018; Matsue et al., 2011), penyakit ginjal $(20 \%-40 \%)$ (Gheith, Farouk, Nampoory, Halim, \& AlOtaibi, 2016), hipertensi (69.8\% - 70.7\%) (Eren et al., 2014; Kilonzo et al., 2017; Ziyyat et al., 2014), dan dyslipidemia (71\% - 93.5\%) (Das \& Banik, 2019; Daya et al., 2017). Di sisi lain, adanya penyakit kronik lain atau munculnya komplikasi diabetes tidak hanya meningkatkan angka hospitalisasi dan kunjungan unit gawat darurat (Lin, Kent, Winn, Cohen, \& Neumann, 2015; Swami \& Korytkowski, 2017), memperpajang jumlah hari rawat (Enomoto, Shrestha, Rosenthal, Hollenbeak, \& Gabbay, 2017) dan menurunkan kualitas hidup (Adriaanse, Drewes, van der Heide, Struijs, \& Baan, 2016; Rahaman et al., 2017), tetapi akan berisiko menurunkan prognosis serta meningkatkan angka kematian (Ang, Heng, Saxena, Liew, \& Chong, 2016; Palsson \& Patel, 2014).

Dengan angka kejadian dan angka komplikasi yang tinggi serta perawatan yang komplek, pencegahan DM merupakan satu strategi terbaik untuk mengatasi masalah kesehatan terkait DM. Penelitian membuktikan bahwa faktor risiko tertinggi menderita DM pada individu dalah faktor gaya hidup (Omolafe et al., 2010) dan 60\% faktor risiko tersebut dapat dicegah melalui intervensi gaya hidup (Taylor et al., 2013). Dengan demikian, meskipun diabetes merupakan penyakit yang tidak dapat disembuhkan, DM dapat dicegah melalui penerapan gaya hidup sehat (Soelistijo et al., 2019; Trisnawati \& Setyorogo, 2013).
Salah satu kelompok yang berisiko tinggi menderita DM adalah keluarga penderita DM. Penelitian menemukan bahwa riwayat DM pada anggota keluarga merupakan satu faktor independen penyebab kejadian DM (Sakurai et al., 2013). Selain itu, riwayat DM dalam keluarga juga ditemukan berhubungan secara signifikan dengan peningkatan 2 - 5 kali lipat risiko untuk menderita DM tipe 2 (Scott et al., 2013). Walaupun demikian, penelitian di Indonesia justru menemukan bahwa keluarga pasien DM tipe 2 cenderung abai dan memiliki perilaku pencegahan yang buruk (Fathania et al., 2015; Hafsari et al., 2015).

Upaya pencegahan sendiri dapat terlaksana jika individu memiliki keyakinan yang kuat untuk mengambil suatu tindakan kesehatan. Becker (1974, dalam Glanz, Rimer, \& Viswanath, 2008) mengatakan bahwa perilaku kesehatan ditentukan oleh dua keyakinan, yakni keyakinan terhadap adanya ancaman kesehatan dari suatu penyakit (kerentanan dan keparahan) serta keyakinan terkait manfaat dan hambatan dalam melakukan tindakan/perilaku pencegahan. Semakin kuat keyakinan individu bahwa dirinya rentan untuk terkena penyakit, penyakit tersebut serius, yakin akan adanya manfaat melakukan pencegahan dan yakin bahwa tidak ada hambatan berarti untuk melakukan pencegahan, maka akan semakin besar kemungkinan individu menjalankan perilaku pencegahan yang diharapkan. Dengan kata lain, baik buruknya perilaku pencegahan pada individu yang memiliki risiko menderita DM bergantung pada seberapa jauh pemahaman dan keyakinan tentang risiko menderita DM dan keyakinan terhadap upaya pencegahan (Dorman et al., 2012).

Penelitian sebelumnya di Wilayah Kerja Puskesmas Jatinangor menemukan bahwa keluarga pasien DM cenderung tidak melakukan upaya pencegahan DM, meskipun sebagian mereka mengetahui bahwa mereka adalah kalangan berisiko 
(Hafsari et al., 2015). Penelitian terkait tingkat keyakinan terhadap pencegahan DM pada dasarnya sudah dilakukan, namun penelitian ini dilakukan pada remaja usia sekolah di Arab Saudi bukan pada keluarga penderita yang secara genetic berisiko menderita DM (Al-Mutairi et al., 2015). Dengan demikian menjadi penting mengidentifikasi lebih lanjut tingkat keyakinan anggota keluarga penderita DM terkait upaya pencehagan DM sekaligus mengidentifikasi faktor apa saja yang berkontribusi terhadap keyakinan tersebut.

Penelitian ini ditujukan untuk mengidentifikasi tingkat keyakinan keluarga penderita DM terhadap upaya pencegahan DM beserta faktor-faktor yang berkontribusi terhdadap keyakinan tersebut.

\section{METODE}

Penelitian deskriptif korelasional ini dilakukan di Wilayah Kerja Puskesmas Jatinangor Kabupaten Sumedang dan mendapatkan izin etik penelitian dari Komisi Etik Penelitian Universitas Padjadjaran Bandung nomor: 379/UN6.KEP/EC/2018. Berdasarkan data dari pihak puskesmas, ada 46 pasien DM tipe 2 yang berobat ke Puskesmas Jatinangor. Dari jumlah tersebut, peneliti (penulis kedua) melakukan kunjungan rumah sesuai data dari pihak puskesmas dan mengambil sampel secara purposive sampling dengan kriteria keluarga pasien DM tipe 2 (anak/saudara kandung) yang bertempat tinggal di Wilayah Kerja Puskesmas Jatinangor, berusia $>12$ tahun, serta dapat membaca dan menulis. Dari penelusuran tersebut didapatkan 72 orang teridir dari 54 anak kandung dan 18 orang saudara kandung penderita DM yang menyatakan bersedia berpartisipasi dalam penelitian ini.

Responden yang menyatakan persetujuan kemudian diminta mengisi kuesioner terkait data demografi dan informasi kesehatan lainnya serta keyakinan mereka terhadap pencegahan DM menggunakan kuesioner Health Belief Model (HBM) yang dikembangkan tim peneliti. Kuesioner HBM dikembangkan oleh tim peneliti berdasarkan Health Belief Model, berisi 6 domain dan 37 item pernyataan. Awalnya, kuesioner ini terdiri dari 39 pernyataan dan setelah didiskusikan dalam tim dan ditanyakan ke pasien (face validity), terdapat 2 item yang dinilai tidak valid. Sebanyak 37 item pernyataan terdistribusi ke dalam 6 domain keyakinan; kerentanan (4 item), keseriusan (4 item), manfaat (7 item), hambatan (9 item), petunjuk bertindak (5 item) dan efikasi diri (8 item). Tiap pernyataan pada domain keyakinan HBM; kerentanan, keseriusan, hambatan, manfaat, dan cues to action memiliki 4 opsi jawaban (sangat setuju (4), setuju (3), tidak setuju (2), dan sangat tidak setuju (1), adapun aspek self-efficacy memiliki 4 opsi jawaban (sangat yakin (4), yakin (3), tidak yakin (2) dan sangat tidak yakin (1). Hasil uji validitas dan realibilitas pada penelitian ini mendapatkan nilai validitas pada rentang 0,383-0,845 dan nilai cronbach's alpha sebesar 0,720 .

Data yang terkumpul kemudian dianalisis secara deskriptif dengan menghitung nilai mean pada masing-masing domain dan nilai mean yang lebih tinggi menunjukkan keyakinan (perceived belief) yang lebih positif. Keyakinan setiap responden akan dikategorikan berdasarkan skor mean masing-masing responden pada setiap domain. Jika skor mean responden pada setiap domain $<3$ maka individu tersebut dikategorikan berkeyakinan negatif dan sebaliknya. Selanjutnya, untuk mengidentifikasi faktor yang berkontribusi terhadap keyakinan anggota keluarga, data keyakinan tersebut dianalisis lanjut baik dengan uji beda atau analisis hubungan berdasarkan data demografi dan/atau data informasi kesehatan yang berhasil dikumpulkan. 


\section{HASIL}

Berdasarkan karakteristik responden didapatkan bahwa sebagian besar responden berusia <45 tahun $(81,9 \%)$, anak kandung dari pasien DM (75\%), tidak pernah mendapatkan penyuluhan terkait DM (75\%), mengetahui bahwa ia berisiko terkena DM di kemudian hari (667\%), berjenis kelamin perempuan $(59,7 \%)$, terlibat dalam perawatan keluarga yang menderita DM (56,9\%), dan berada pada tingkat pendidikan SMA (51,4\%). Adapun pekerjaan responden hampir sebagian berprofesi sebagai pelajar $(33,3 \%)$.

\section{Keyakinan Terkait DM dan Pencegahan DM}

Hasil penelitian menunjukkan bahwa rerata skor kedua tertinggi ditemukan pada keyakinan akan manfaat $(3,31)$ dan keyakinan akan kerentanan $(3,19)$. Adapun rerata skor kedua terendah ditemukan pada domain efikasi diri $(2,57)$ dan keykinan akan hambatan $(2,46)$. Hal ini mengindikasikan bahwa sebagain besar responden cenderung berkeyakinan bahwa sebagai keluarga penderita diabetes mereka rentan $(77,78 \%)$ terkena DM dan karenanya sebagian besar mereka $(84,70 \%)$ juga meyakini akan adanya manfaat dalam melakukan upaya pencegahan diabetes mellitus. Meski demikian, sebagian besar mereka meyakini adanya hambatan dalam melakukan upaya pencegahan $(80 \%)$ serta merasa tidak yakin $(77,78 \%)$ mampu menjalankan upaya pencegahan DM.

Selain itu, keyakinan yang tinggi terkait manfaat pencegahan cenderung ditemukan pada responden dengan keyainan yang tinggi akan kerentanan ( $\mathrm{r}=0,38 ; p=0,001)$, keparahan $(\mathrm{r}=0,29 ; p=0,015)$, petunjuk bertindak $(\mathrm{r}=0,45 ; p=0,00)$, dan efikasi $\operatorname{diri}(\mathrm{r}=0,345 ; p=0,003)$.

Penelitian ini juga menemukan bahwa keyakinan pada beberapa domain berbeda secara signifikan berdasarkan karakteristik responden. Responden perempuan memiliki keyakinan yang lebih tinggi dibandingkan responden laki-laki baik pada domain kerentanan $(p=0,016)$ dan manfaat $(p=0,048)$. Keyakinan akan kerentanan juga ditemukan lebih tinggi pada responden yang terlibat langsung dalam perawatan penderita DM $(p=0,001)$. Selain itu, tingkat keyakinan akan keseriusan penyakit DM secara signifikan lebih tinggi ditemukan pada responden yang terlibat langsung dalam perawatan penderita DM $(p=0,019)$ maupun mengaku mengetahui bahwa dirinya berisiko menderita DM ( $p=0,000)$. Namun, tidak ditemukan adanya perbedaan tingkat keyakinan yang bermakna pada keseluruhan domain keyakinan baik berdasarkan usia responden maupun riwayat kesehatanya. 
Tabel 1

Distribusi Frekuensi dan Persentase Karakteristik Responden ( $\mathrm{n}=72)$

\begin{tabular}{|c|c|c|c|}
\hline Indikator & & $\mathrm{f}$ & $\%$ \\
\hline \multirow[t]{2}{*}{ Usia (Mean $=31,028 \pm 13,22$ ) } & $<45$ & 59 & 81,9 \\
\hline & $\geq 45$ & 13 & 18,1 \\
\hline \multirow[t]{2}{*}{ Jenis Kelamin } & Laki-laki & 29 & 40,3 \\
\hline & Perempuan & 43 & 59,7 \\
\hline \multirow[t]{4}{*}{ Pendidikan } & SD & 3 & 4,2 \\
\hline & SMP & 7 & 9,7 \\
\hline & SMA & 37 & 51,4 \\
\hline & PT & 25 & 34,7 \\
\hline \multirow[t]{5}{*}{ Pekerjaan } & IRT & 16 & 22,2 \\
\hline & Pelajar & 24 & 33,3 \\
\hline & Buruh & 16 & 22,2 \\
\hline & Wiraswasta & 13 & 18,1 \\
\hline & PNS & 3 & 4,2 \\
\hline \multirow[t]{2}{*}{ Hubungan dengan pasien DM } & Anak kandung & 54 & 75,0 \\
\hline & Saudara Kandung & 18 & 25,0 \\
\hline \multirow[t]{2}{*}{ Riwayat Penyuluhan DM } & Pernah & 18 & 25,0 \\
\hline & Tidak Pernah & 54 & 75,0 \\
\hline \multirow[t]{2}{*}{ Tahu berisiko DM } & Tahu & 48 & 67 \\
\hline & Tidak tahu & 24 & 33 \\
\hline \multirow[t]{2}{*}{ Terlibat dalam perawatan pasien DM } & $\mathrm{Ya}$ & 41 & 56,9 \\
\hline & Tidak & 31 & 43,1 \\
\hline \multirow[t]{4}{*}{ Riwayat Kesehatan } & Sehat & 42 & 58,3 \\
\hline & Hipertensi & 17 & 23,6 \\
\hline & Gula Darah Tinggi & 9 & 12,5 \\
\hline & Hipertensi dan Gula Darah Tinggi & 4 & 5,6 \\
\hline
\end{tabular}

Tabel 2

Distribusi Mean Tiap Domain Keyakinan Terkait DM dan Pencegahan DM serta Hubungan Satu Domain dengan Domain Lainnya $(\mathrm{n}=72)$

\begin{tabular}{|c|c|c|c|c|c|c|c|c|}
\hline \multirow{2}{*}{$\begin{array}{c}\text { Domain Keyakinan } \\
\text { Berdasarkan Teori } \\
\text { Health Belief Model } \\
\text { (HBM) }\end{array}$} & \multirow[b]{2}{*}{ Mean (SD) } & \multicolumn{2}{|c|}{ Kategori keyakinan } & \multicolumn{5}{|c|}{ Skor r (korelasi, $p$ ) } \\
\hline & & $\begin{array}{l}\text { Positif } \\
\mathrm{f}(\%)\end{array}$ & $\begin{array}{c}\text { Negatif } \\
\text { f (\%) }\end{array}$ & Keseriusan & Manfaat & Hambatan & $\begin{array}{l}\text { Petunjuk } \\
\text { bertindak }\end{array}$ & $\begin{array}{c}\text { Efikasi } \\
\text { diri }\end{array}$ \\
\hline Persepsi Kerentanan & $3,19(0,47)$ & $56(77,78)$ & $16(22,22)$ & $r=0,37$ & $r=0,38$ & $r=0,98$ & $r=0,111$ & $r=0,11$ \\
\hline (4 item; $4-16)$ & & & & $p=0,002$ & $p=0,001$ & $p=0,41$ & $p=0,36$ & $p=0,36$ \\
\hline Persepsi Keseriusan & $3,09(0,45)$ & $43(59,72)$ & $29(40,28)$ & & $r=0,29$ & $r=-0,16$ & $r=0,08$ & $r=-0,96$ \\
\hline (4 item; $4-16)$ & & & & - & $p=0,015$ & $p=0,19$ & $p=0,53$ & $p=0,42$ \\
\hline Persepsi Manfaat (7 & $3,31(0,39)$ & $61(84,70)$ & $11(15,30)$ & - & - & $r=-0,05$ & $r=0,45$ & $r=0,263$ \\
\hline item; 7 - 28) & & & & & & $p=0,69$ & $p=0,00$ & $p=0,026$ \\
\hline Persepsi Hambatan & $2,46(0,44)$ & $12(17)$ & $60(83)$ & & & & $r=-0,017$ & $r=0,202$ \\
\hline (9 item; $9-36)$ & & & & - & - & - & $p=0,89$ & $p=0,089$ \\
\hline Petunjuk Bertindak & $3,08(0,33)$ & $55(76,4)$ & $17(23,60)$ & & & & & $r=0,345$ \\
\hline$(5$ item; $5-20)$ & & & & - & - & - & - & $p=0,003$ \\
\hline Efikasi Diri (8 item; 8 & $2,57(0,66)$ & $16(22,22)$ & $56(77,78)$ & & & & & \\
\hline-32$)$ & & & & - & - & - & - & - \\
\hline
\end{tabular}


Tabel 3

Perbedaan Keyakinan Domain Berdasarkan Karakteristik Responden ( $n=72)$

\begin{tabular}{|c|c|c|c|c|c|c|c|c|c|c|c|c|}
\hline \multirow[t]{2}{*}{ Indikator } & \multicolumn{2}{|c|}{ Kerentanan } & \multicolumn{2}{|c|}{ Keseriusan } & \multicolumn{2}{|c|}{ Manfaat } & \multicolumn{2}{|c|}{ Hambatan } & \multicolumn{2}{|c|}{$\begin{array}{c}\text { Petunjuk } \\
\text { Bertindak }\end{array}$} & \multicolumn{2}{|c|}{ Self-efficacy } \\
\hline & Mean & $p$ & Mean & $p$ & Mean & $p$ & Mean & $p$ & Mean & $p$ & Mean & $p$ \\
\hline \multicolumn{13}{|l|}{ Gender } \\
\hline Male & 3,04 & 0,016 & 2,99 & 0,12 & 3,19 & 0,048 & 2,46 & 0,24 & 3,06 & 0,79 & 3,36 & 0,14 \\
\hline Female & 3,30 & & 3,16 & & 3,39 & & 2,58 & & 3,08 & & 3,13 & \\
\hline \multicolumn{13}{|l|}{ Usia } \\
\hline$\geq 45$ tahun & 3,17 & 0,43 & 3,12 & 0,32 & 3,28 & 0,24 & 2,49 & 0,08 & 3,08 & 0,87 & 3,22 & 0,99 \\
\hline$<45$ tahun & 3,29 & & 2,98 & & 3,43 & & 2,72 & & 3,06 & & 3,22 & \\
\hline \multicolumn{13}{|l|}{$\begin{array}{l}\text { Mengetahui } \\
\text { berisiko }\end{array}$} \\
\hline Tahu & 3,23 & 0,31 & 3,22 & 0,000 & 3,29 & 0,59 & 2,53 & 0,92 & 3,02 & 0,047 & 3,24 & 0,79 \\
\hline Tidak tahu & 3,12 & & 2,83 & & 3,35 & & 2,54 & & 3,18 & & 3,19 & \\
\hline \multicolumn{13}{|c|}{$\begin{array}{l}\text { Keterlibatan } \\
\text { dalam perawatan } \\
\text { pasien DM }\end{array}$} \\
\hline Terlibat & 3,35 & 0,001 & 3,20 & 0,019 & 3,37 & 0,14 & 2,53 & 0,99 & 3,10 & 0,51 & 3,25 & 0,72 \\
\hline Tidak & 2,99 & & 2,95 & & 3,23 & & 2,53 & & 3,05 & & 3,19 & \\
\hline \multicolumn{13}{|l|}{ Riwayat } \\
\hline Sehat & 3,27 & 0,11 & 3,09 & 0,92 & 3,35 & 0,35 & 2,55 & 0,67 & 3,12 & 0,18 & 3,32 & 0,13 \\
\hline $\begin{array}{l}\text { Memiliki } \\
\text { penyakit }\end{array}$ & 3,09 & & 3,10 & & 3,25 & & 2,51 & & 3,01 & & 3,08 & \\
\hline \multicolumn{13}{|l|}{$\begin{array}{l}\text { Riwayat } \\
\text { mengikuti } \\
\text { penyuluhan DM }\end{array}$} \\
\hline Pernah & 3,24 & 0,67 & 3,10 & 0,97 & 3,25 & 0,44 & 2,69 & 0,09 & 3,09 & 0,84 & 3,19 & 0,84 \\
\hline Tidak Pernah & 3,18 & & 3,09 & & 3,33 & & 2,48 & & 3,07 & & 3,23 & \\
\hline
\end{tabular}

\section{PEMBAHASAN}

Penelitian ini ditujukan untuk mengidentifikasi keyakinan keluarga penderita DM terkait pencegahan DM di Wilayah Kerja Puskesmas Jatinangor, Jawa Barat. Penelitian ini menemukan bahwa keluargapasien Dm yang menjadi responden dalam penelitian ini cenderung meyakini bahwa dirinya merasa rentan terkena DM. Penelitian ini sejalan dengan temuan penelitian (Whitford et al., 2009) yang menemukan bahwa keluarga pendeirta DM cenderung memiliki kesadaran tinggi akan kerentanan mengalami DM. Penelitian tersebut juga menemukan bahwa hampir semua responden menginginkan diberitahu tentang cara mengurangi risiko tersebut. Hal ini sangat penting karena survey di Amerika menemukan bahwa keturunan atau saudara kandung penderita DM meiliki risiko terkena DM 2-5 x lebih tinggi dibanding mereka yang tidak memiliki riwayat DM dalam keluarganya (Scott dkk. 2013). Keyakinan akan kerentanan ini ditemukan lebih tinggi pada responden wanita dan terlibat dalam perawatan penderita DM. Meskipun hanya setengah dari penderita DM menyampaikan informasi terkait risiko DM pada keluarganya (Whitford et al., 2009), dengan terlibat langsung dalam perawatan penderita menjadikan individu lebih banyak terpapar informasi terkait DM termasuk siapa saja yang berisiko menderita DM. Lebih lanjut, responden wanita cenderung memiliki risiko DM (Kautzky-Willer et al., 2016) sekaligus pengetahuan tentang DM yang lebih tinggi dibandingkan reponden laki-laki (Lemes Dos Santos et al., 2014). Dengan demikian anggota keluarga penderita DM yang berjenis kelamin perempuan akan cenderung memiliki keyakinan yang lebih tinggi terkait kerentanan terkena DM.

Responden dalam penlitian ini juga 
cenderung meyakini bahwa DM adalah penyakit yang serius dan keyakinan akan keseriusan ini berhubugan erat dengan keyakinan responden akan kerentanan terkena DM. Temuan ini menguatkan temuan sebleumnya yang menyatakan semakin banyak keluarga yang menderita DM akan semakin meningkatkan persepsi/keyainan anggota keluarga yang sehat tentang keseriusan penyakit DM yang kemudian akan meningkatkan perilaku pencegahan (Amuta et al., 2017). Lebih lanjut, keyakinan akan keseriusan DM ini ditemukan signifikan lebih tinggi pada responden yang mengaku mengetahui bahwa mereka berisiko menderita DM dan terlibat dalam perawatan penderita DM. Pengalaman merawat penderita DM berpotensi besar meningkatkan keterpaparan individu dengan informasi dan fakta terkait DM, kompleksitas perawatan maupun komplikasi dan dampak buruk DM bagi penderita. Semua itu akan semakin menguatkan pemahaman, persepsi dan keyakinan individu akan keseriusan penyakit DM. Penelitian Nishigaki et al., (2008) mengatakan bahwa pemberian informasi yang dilakukan secara personal oleh anggota keluarga yang menderita DM sebagai media penyampaian pesan terkait pencegahan DM lebih menghasilkan perubahan pemahaman sekaligus perilaku gaya hidupnya, dimana salah satunya adalah mau melakukan pemeriksaan (screening). Dengan kata lain, keluarga memiliki fungsi sosialisasi yang memungkinkan adanya interaksi intens antar setiap anggota keluarga, termasuk dalam mengenalkan penyakit yang diderita oleh salah satu anggota keluarga (Efendi \& Makhfudli, 2009).

Terkait keyakinan akan kemanfaatan upaya pencegahan, penelitian ini menemukan bahwa responden dalam penelitian ini memiliki keyakinan yang tertinggi (nilai rerata tertinggi) pada domain ini. Lebih lanjut, keyakinan akan manfaat ini berhubungan secara signifikan dengan keyakinan kerentanan, keseriusan DM, petunjuk bertindak dan efikasi diri.
Maknanya semakin tinggi keyakinan akan DM sebagai penyakit yang serius, merasa rentan terkena DM, memiliki petunjuk bertindak, dan efikasi diri yang tinggi, akan semakin tinggi keyakinan akan kemanfaatan menjalankan upaya pencegahan. Selain itu, penelitian ini menemukan bahwa keyakinan akan manfaat pencegahan DM secara signifikan lebih tinggi pada responden perempuan. Temuan dalam penelitian ini sejalan dengan hasil penelitian Al-Mutairi et al., (2015) yang mendapati bahwa keyakinan kemanfaatan ditemukan secara bermakna lebih tinggi pada reponden perempuan dibandingkan laki-laki. Hal ini disebabkan secara kultural, di Indonesia perempuan lebih bertanggung jawab merawat keluarga termasuk anggota keluarga yang sakit. Dengan keterlibatan dalam perawatan pasien DM yang lebih inten berpotensi meningkatkan tingkat pengetahuan responden perempuan baik tentang kerentanan dan keseriusan penyakit DM yang lebih lanjut akan meningkatkan keyakinanya tentang kebermanfaatan melakukan upaya pencegahan DM. Sebagiamana disampaikan sebelumnya, responden perempuan teridentifikasi memilki pengetahuan tentang DM yang lebih baik dibandingkan responden lakilaki (Lemes Dos Santos et al., 2014).

Meski responden dalam penelitian ini memiliki keyakinan yang tinggi akan kerentanan, keseriusan DM, dan manfaat pencegahan, responden meyakini tingginya hambatan dalam melakukan upaya pencegahan DM. Keyakinan akan hambatan ini tidak berhubungan secara bermakna dengan domain keyakinan HBM yang lain. Meskipun tidak signifikan secara statistik, penelitian ini menemukan bahwa responden berjenis kelamin laki-laki, berusia lebih tua, dan mengaku memiliki penyakit kronik seperti hipertensi dan penyakit kronik lainnya lebih meyakini adanya hambatan dalam menjalankan upaya pencegahan. Dengan usia yang lebih tua dan menderita penyakit kronik berpotensi meningkatkan persepsi akan 
hambatan akibat adanya penurunan kemampuan fisik maupun sumber daya. Sebuah sistematik review menemukan salah satu hambatan terkait program latihan fisik (olahraga) pada lansia dengan diabetes adalah adanya kesalahpahaman di antara lansia di kawasan Asia yang meyakini bahwa latihan fisik justru akan memperburuk kondisi kesehatanya yang ditandai dengan rasa lelah dan sesak nafas setelah olahraga (Sohal et al., 2015).

Terkait jenis kelamin dan keyakinan akan hambatan, hasil penelitian kami sedikit berbeda dengan penelitian Al-Mutairi et al., (2015) yang justru menemukan bahwa keyakinan adanya hambatan melakukan pencegahan lebih banyak ditemukan pada responden perempuan terutama dalam hal mencegah obesitas dan hambatan yang dirasakan paling berat adalah cuaca yang panas dan tidak adanya waktu untuk berolahraga. Penelitian lain juga menemukan bahwa responden perempuan secara signifikan memiliki masa sedentary life (tidak aktif secara fisik) lebih lama dan memiliki motivasi yang lebih rendah untuk melakukan olahraga dibandingkan laki-laki (Kadariya \& Aro, 2018). Analisis lebih lanjut skor item dalam hambatan, penelitian kami menemukan bahwa hambatan terbesar yang diyakini responden dalam menjalankan pencegahan DM adalah mengelola/menurunkan kegemukan. Sohal et al., (2015) mendapati bahwa salah satu kesulitan mengelola kegemukan/ obesitas di antara penderita DM dari Etnis Asia adalah masih adanya keyakinan kultural yang menganggap bahwa kegemukan adalah ciri kesejahteraan dan kesehatan yang justru menghambat mereka berpartisipasi aktif dalam program.

Responden dalam penelitian ini juga teridentifikasi memiliki keyakinan/ efikasi diri yang rendah. Responden merasa paling tidak yakin untuk menjalankan diet sehat dan seimbang terutama saat menghadiri pesta. Temuan ini sejalan dengan temuan sebuah sistematik review yang mencatat bahwa salah satu kesulitan utama dalam mengadopsi program diet di antara penderita diabetes mellitus di kawasan Asia adalah menghindari makanan tradisional dan makanan yang disajikan dalam agenda budaya/adat/acara sosial. Mereka cenderung mengutamakan hubungan sosial kemasyarakatan dan mengabaikan program diet saat menghadiri acara (pesta) tersebut (Sohal et al., 2015). Dalam penelitian kami, keyakinan akan efikasi diri ditemukan berhubungan secara bermakna dengan keyakinan akan kemanfaatan pencegahan. Dengan kata lain, bila responden mendapatkan penguatan yang signifikan terkait kemanfaatan akan berpotensi meningkatkan efikasi diri responden untuk menjalankan upaya pencegahan DM. Hal ini sangat penting, karena penelitian menemukan bahwa individu prediabetes yang memiliki efikasi diri tinggi, mereka menunjukkan adanya perubahan yang signifikan dalam melakukan perilaku pencegahan dan dapat menurunkan risiko terkena DM sebanyak 30\% (Aguiar et al., 2016). Sejalan dengan temuan tersebut, penelitian Serrano, Leiferman, \& Dauber, (2007) yang mengatakan bahwa individu dengan efikasi diri yang tinggi cenderung lebih berpotensi mengubah kebiasaan makan dan mengendalikan berat badannya jika mereka berisiko mengidap diabetes mellitus.

Tingkat keyakinan responden dalam penelitian ini ditemukan berhubungan secara bermakna dengan petunjuk bertindak. Hal ini mengindikasikan bahwa keyakinan dan kecenderungan untuk melakukan pencegahan pada responden dalam penelitian ini sebagian besar dipengaruhi oleh petunjuk-petunjuk eksternal. Temuan ini sejalan dengan apa yang dituliskan Bitton, Flier, and Jha (2012) yang mencatat bahwa implementasi media cetak maupun elektronik memiliki fungsi penting dalam penyampaian informasi kesehatan dan pencegahan penyakit. Penggunaan teknologi informasi juga memiliki manfaat yang berarti baik bagi 
peningkatan kualitas perawatan DM, promosi kesehatan, maupun upaya pencegahan DM (Ahmad \& Tsang, 2013).

\section{SIMPULAN}

Penelitian ini ditujukan untuk mengidentifikasi tingkat keyakinan keluarga penderita DM terhadap pencegahan DM dan faktor yang berkontribusi terhadapnya. Dari uraian di atas dapat disimpulkan bahwa, keluarga penderita DM di Wilayah Kerja Puskesmas Jatinangor Jawa Barat memiliki keyakinan yang kuat akan kerentanan, keseriusan DM, kemanfaatan dan petunjuk bertindak termasuk keyakinan akan tingginya hambatan dan rendahnya efikasi diri untuk melakukan pencegahan DM. Faktor yang berkontribusi terhadap keyakinan akan kerentanan terkena DM adalah jenis kelamin perempuan dan keterlibatan responden dalam perawatan pasien. Faktor yang berkontribusi terhadap keyakinan akan keseriusan penyakit DM adalah mengetahui bahwa dirinya berisiko dan terlibat dalam perawatan pasien DM. Faktor yang berkontribusi terhadap keyakinan akan kemanfaatan adalah keyakinan akan kerentanan, keseriusan, petunjuk bertindak, dan efikasi diri. Dengan demikian menjadi penting bagi petugas kesehatan dan pihak puskesmas untuk meningkaktan keterlibatan keluarga dalam perawatan penderita DM serta mengedukasi keluarga terkait manfaat pencegahan DM. Di sisi lain, penting bagi pihak puskesmas dan keluarga untuk mengidentifikasi lebih lanjut hambatan keluarga dalam melakukan pencegahan DM beserta cara meminimalisir hambatan tersebut.

\section{UCAPAN TERIMAKASIH}

Terimakasih yang sebanyak-banyaknya kami sampaikan kepada semua pihak yang telah berkontribusi terhadap penelitian ini, terutama pasien DM beserta keluarganya yang telah bersedia berpartisipasi dan membagikan informasi yang berharga dalam penelitian ini serta pihak puskesmas yang telah mengijinkan penelitian ini dan membantu menghubungkan tim peneliti dengan pasien DM dan/keluarganya.

\section{REFERENSI}

Adriaanse, M. C., Drewes, H. W., van der Heide, I., Struijs, J. N., \& Baan, C. A. (2016). The impact of comorbid chronic conditions on quality of life in type 2 diabetes patients. Quality of Life Research, 25(1), 175-182. https://doi.org/10.1007/s11136-015-1061-0

Aguiar, E. J., Morgan, P. J., Collins, C. E., Plotnikoff, R. C., Young, M. D., \& Callister, R. (2016). Efficacy of the Type 2 Diabetes Prevention Using LifeStyle Education Program RCT. American Journal of Preventive Medicine, 50(3), 353-364. https://doi.org/10.1016/j.amepre.2015.08.02 0

Ahmad, F. S., \& Tsang, T. (2013). Diabetes prevention, health information technology, and meaningful use: Challenges and opportunities. American Journal of Preventive Medicine, 44(4 SUPPL.4), S357-S363.

https://doi.org/10.1016/j.amepre.2012.12.02 0

Al-Mutairi, R. L., Bawazir, A. A., Ahmed, A. E., \& Jradi, H. (2015). Health beliefs related to diabetes mellitus prevention among adolescents in Saudi Arabia. Sultan Qaboos University Medical Journal, 15(3), e398-e404. https://doi.org/10.18295/squmj.2015.15.03. 015

Amuta, A. O., Mkuu, R., Jacobs, W., \& Barry, A. E. (2017). Number and Severity of Type 2 Diabetes among Family Members Are Associated with Nutrition and Physical Activity Behaviors. Frontiers in Public Health, 5(July), 17. https://doi.org/10.3389/fpubh.2017.00157

Ang, Y. G., Heng, B. H., Saxena, N., Liew, S. T. A., \& Chong, P. N. (2016). Annual all-cause mortality rate for patients with diabetic kidney disease in Singapore. Journal of Clinical and Translational Endocrinology, $\quad 4, \quad 1-6$. https://doi.org/10.1016/j.jcte.2016.01.002

Bitton, A., Flier, L. A., \& Jha, A. K. (2012). Health information technology in the era of care delivery reform: To what end? JAMA - Journal of the American Medical Association, 307(24), 2593-2594.

https://doi.org/10.1001/jama.2012.6663

Das, H., \& Banik, S. (2019). Diabetes \& Metabolic Syndrome: Clinical Research \& Reviews Prevalence of dyslipidemia among the diabetic patients in southern Bangladesh: A crosssectional study. Diabetes \& Metabolic Syndrome: Clinical Research \& Reviews, 13(1), 
252-257.

https://doi.org/10.1016/j.dsx.2018.09.006

Daya, R., Bayat, Z., \& Raal, F. J. (2017). Prevalence and pattern of dyslipidaemia in type 2 diabetes mellitus patients at a tertiary care hospital Prevalence and pattern of dyslipidaemia in type 2 diabetes mellitus patients at a tertiary care hospital. Journal of Endocrinology, Metabolism and Diabetes of South Africa, 22(3), 31-35.

https://doi.org/10.1080/16089677.2017.136 0064

Dorman, J. S., Veldez, R., Liu, T., Wang, C., Rubinstein, W. S., O'Neill, S. M., \& Acheson, L. S. (2012). Health beliefs among individuals at increased familial risk for type 2 diabetes: Implications for prevention. Diabetes Research and Clinical Practice, 96(2), 156-162. https://doi.org/10.1016/j.diabres.2011.12.01 7.Health

Efendi, F., \& Makhfudli. (2009). Keperawatan kesehatan komunitas: Teori dan praktik dalam keperawatan . Jakarta: Salemba Medika. Salemba Medika.

Einarson, T. R., Acs, A., Ludwig, C., \& Panton, U. H. (2018). Prevalence of cardiovascular disease in type 2 diabetes: A systematic literature review of scientific evidence from across the world in 2007-2017. Cardiovascular Diabetology, 17(1), 1-19. https://doi.org/10.1186/s12933-0180728-6

Enomoto, L. M., Shrestha, D. P., Rosenthal, M. B., Hollenbeak, C. S., \& Gabbay, R. A. (2017). Risk factors associated with 30-day readmission and length of stay in patients with type 2 diabetes. Journal of Diabetes and Its Complications, 31(1), 122-127. https://doi.org/10.1016/j.jdiacomp.2016.10.0 21

Eren, N. K., Harman, E., Dolek, D., Tütüncüoğlu, A. P., Emren, S. V., Levent, F., Korkmaz, G., Tutluce, S. Y., \& Nazli, C. (2014). Rate of blood pressure control and antihypertensive treatment approaches in diabetic patients with hypertension. Türk Kardiyoloji Derneği Arșivi, 42(8), $\quad$ 733-740. https://doi.org/10.5543/tkda.2014.53384

Fathania, D., Nursiswati, \& Pristasari, S. (2015). Hubungan Persepsi dengan Perilaku Pencegahan Penyakit pada Individu dengan Riwayat Turunan Diabetes Melitus Tipe 2 di Wilayah Kerja Puskesmas Pasir Kaliki Kota Bandung. Universitas Padjadjaran.

Gheith, O., Farouk, N., Nampoory, N., Halim, M. A., \& Al-Otaibi, T. (2016). Diabetic kidney disease: world wide difference of prevalence and risk factors. Journal of Nephropharmacology, 5(1),
49-56. https://doi.org/10.3969/j.issn.10011242.2011.08.027

Hafsari, T., Desriyani, Y., Susanti, A., Nurkarimah, A., Pebriyanti, A., \& Kurniawan, T. (2015). Deteksi dini diabetes melitus tipe 2 melalui keluarga di Kecamatan Jatinangor (Vol. 2015).

International Diabetes Federation [IDF]. (2019). IDF Diabetes Atlas; Ninth edition 2019 (B. Malanda, S. Karuranga, P. Saeedi, \& P. Salpea (eds.); 9th ed.).

Kadariya, S., \& Aro, A. R. (2018). Barriers and facilitators to physical activity among urban residents with diabetes in Nepal. PLOS ONE, 13(6), 1-21. https://doi.org/10.1371/journal.pone.019932 9

Kautzky-Willer, A., Harreiter, J., \& Pacini, G. (2016). Sex and gender differences in risk, pathophysiology and complications of type 2 diabetes mellitus. Endocrine Reviews, 37(3), 278-316. https://doi.org/10.1210/er.20151137

Kilonzo, S. B., Gunda, D. W., Bakshi, F. A., Kalokola, F., Mayala, H. A., \& Dadi, H. (2017). Control of Hypertension among Diabetic Patients in a Referral Hospital in Tanzania: A CrossSectional Study. Ethiopian Journal of Health Science, 27(5), 473-480.

Law, K. Z., Nafisah, W. N., Sahathevan, R., Yong, J., Zakaria, M. F., Shuhari, N. M. M., Ahmad, Nur Fathihah, N., Ting, T. K., Tan, H. J., Azmin, S., Remli, R., Nawi, A. M., \& Ibrahim, N. M. (2015). High prevalence of diabetes in stroke patients and its association with lacunar infarction. Neurology Asia, 20(2), 121-127.

Lemes Dos Santos, P. F., Dos Santos, P. R., Ferrari, G. S. L., Fonseca, G. A. A., \& Ferrari, C. K. B. (2014). Knowledge of diabetes mellitus: Does gender make a difference? Osong Public Health and Research Perspectives, 5(4), 199-203. https://doi.org/10.1016/j.phrp.2014.06.004

Lin, P.-J., Kent, D. M., Winn, A., Cohen, J. T., \& Neumann, P. J. (2015). Multiple Chronic Conditions in Type 2 Diabetes Mellitus: Prevalence and Consequences. American Journal of Managed Care, 21(January 2015 1).

Matsue, Y., Suzuki, M., Nakamura, R., Abe, M., Ono, M., Yoshida, S., Seya, M., \& Iwatsuka, R. (2011). Prevalence and Prognostic Implications of PreDiabetic State in Patients With Heart Failure. Circulation Journal, 75(December). https://doi.org/10.1253/circj.CJ-11-0754

Nishigaki, M., Kobayashi, K., Abe, Y., Seki, N., Yokomura, T., Yokoyama, M., \& Kazuma, K. (2008). Preventive behaviour in adult offspring of Type 2 diabetic patients and its relationship 
to parental advice. Diabetic Medicine, 25(11), 1343-1348. https://doi.org/10.1111/j.14645491.2008.02582.x

Omolafe, A., Mouttapa, M., McMahan, S., \& Tanjasiri, S. P. (2010). We are Family: Family History of Diabetes among African Americans and its Association to Perceived Severity, Knowledge of Risk Factors, and Physical Activity Levels. Californian Journal of Health Promotion, 8(1), 88-97.

https://doi.org/10.32398/cjhp.v8i1.2034

Palsson, R., \& Patel, U. D. (2014). Cardiovascular Complications of Diabetic Kidney Disease. Advance Chronic Kidney Disease, 21(3), 273280.

https://doi.org/10.1053/j.ackd.2014.03.003.

Pusat Data dan informasi Kementerian Keseahatan RI. (2014). InfoDATIN; Situasi dan Analisis Diabetes. In Kementerian Kesehatan Republik Indonesia.

Rahaman, K., Majdzadeh, R., Naieni, K., \& Raza, 0. (2017). Comorbidities and Care Practices of Diabetic Patients. Austin Journal of Public Health and Epidemiology, 4(2), 1-6. https://doi.org/10.26420/austinjpublichealth epidemiol.2017.1059

Rao, K. V. M., \& Reddy, G. P. K. (2016). Prevalence of diabetes among stroke patients : a study in a tertiary care centre. International Journal of Advance in Medicine, 3(2), 189-193.

Sakurai, M., Nakamura, K., Miura, K., Takamura, T., Yoshita, K., Sasaki, S., Nagasawa, S. Y., Morikawa, Y., Ishizaki, M., Kido, T., Naruse, Y., Suwazono, Y., \& Nakagawa, H. (2013). Family history of diabetes, lifestyle factors, and the 7year incident risk of type 2 diabetes mellitus in middle-aged japanese men and women. Journal of Diabetes Investigation, 4(3), 261-268. https://doi.org/10.1111/jdi.12033

Scott, R. A., Langenberg, C., Sharp, S. J., Franks, P. W., Rolandsson, O., Drogan, D., van der Schouw, Y. T., Ekelund, U., Kerrison, N. D., Ardanaz, E., Arriola, L., Balkau, B., Barricarte, A., Barroso, I., Bendinelli, B., Beulens, J. W. J., Boeing, H., de Lauzon-Guillain, B., Deloukas, P., ... Wareham, N. J. (2013). The link between family history and risk of type 2 diabetes is not explained by anthropometric, lifestyle or genetic risk factors: The EPIC-InterAct study. Diabetologia, 56(1), 60-69. https://doi.org/10.1007/s00125-012-2715-x

Serrano, E., Leiferman, J., \& Dauber, S. (2007). Self- efficacy and health behaviors toward the prevention of diabetes among high risk individuals living in appalachia. Journal of Community Health, 32(2), 121-133. https://doi.org/10.1007/s10900-006-9034-4

Soelistijo, S. A., Lindarto, D., Decroli, E., Permana, H., Sucipto, K. W., Kusnadi, Y., Budiman, \& Ikhsan, R. (2019). Pedoman pengelolaan dan pencegahan diabetes melitus tipe 2 dewasa di Indonesia 2019 (Consensus - Management and prevention of type 2 diabetes mellitus in Indonesia). Perkumpulan Endokrinologi Indonesia, 1-117.

Sohal, T., Sohal, P., King-Shier, K. M., \& Khan, N. A. (2015). Barriers and facilitators for type-2 diabetes management in south asians: A systematic review. PLoS ONE, 10(9), 1-15. https://doi.org/10.1371/journal.pone.013620 2

Swami, J., \& Korytkowski, M. (2017). The futile cycle of hospital readmission in patients with diabetes. Journal of Diabetes and Its Complications, 31(8), 1252-1253. https://doi.org/10.1016/j.jdiacomp.2017.06.0 06

Taylor, J., Cottrell, C., Chatterton, H., Hill, J., Hughes, R., Wohlgemuth, C., \& Holt, R. I. G. (2013). Identifying risk and preventing progression to Type 2 diabetes in vulnerable and disadvantaged adults: A pragmatic review. Diabetic Medicine, 30(1), 16-25. https://doi.org/10.1111/dme.12027

Trisnawati, S. K., \& Setyorogo, S. (2013). Faktor Risiko Kejadian Diabetes Melitus Tipe II Di Puskesmas Kecamatan Cengkareng Jakarta Barat Tahun 2012. Jurnal Ilmiah Kesehatan, 5(1), 6-11.

Whitford, D. L., McGee, H., \& O’Sullivan, B. (2009). Reducing health risk in family members of patients with type 2 diabetes: Views of first degree relatives. BMC Public Health, 9, 1-10. https://doi.org/10.1186/1471-2458-9-455

World Health Organization [WHO]. (2018). Noncommunicable Diseases Country Profiles 2018. In World Health Organization [WHO]. https://doi.org/16/j.jad.2010.09.007

Ziyyat, A., Ramdani, N., Bouanani, N. E. H., Vanderpas, J., Hassani, B., Boutayeb, A., Aziz, M., Mekhfi, H., Bnouham, M., \& Legssyer, A. (2014). Epidemiology of hypertension and its relationship with type 2 diabetes and obesity in eastern Morocco. Springer Plus, 3(644), 1-7. 